Marija Nikolić Tošovićc ${ }^{*}$, Violeta Jovanović ${ }^{2}$

${ }^{1}$ LUM Jean Monnet University, Faculty of Economics, Italy ${ }^{2}$ Megatrend University, Faculty of Management Zaječar, Serbia

\title{
Entrepreneurial Intention Model: Empirical Results with Management Students in Serbia
}

\author{
DOI:10.7595/management.fon.2020.0023
}

\begin{abstract}
:
Research Question: This paper analyses which elements influence the entrepreneurial intention in Serbian entrepreneurial practice. Motivation: With this research, we want to draw attention of the public, decision-makers and entrepreneurs to entrepreneurship as a huge potential for the nation's long-term economic growth in Serbia. To enlarge the number of potential entrepreneurs and, therefore, the final number of entrepreneurs, a more detailed explanation of all the phases as well as the prediction of entrepreneurship is necessary. As far as the first phase is concerned, this research starts from the adoption of the theory of planned behaviour (Ajzen, 1991) and tests relative contributions of motivational antecedents to the entrepreneurial intention (EI). Mixed results from literature for model specifications, especially for the contribution of subjective norm (SN), lead to the general need for more empirical support. Idea: Considering findings that the influence of motivational antecedents on El differs due to national cultures (Linan \& Chen, 2009), we conducted the empirical investigation to test the model in the context of Serbian entrepreneurial practice. Data: Primary data were collected from 191 responses to the questionnaire distributed among the students of Master management studies and junior and senior students of undergraduate management studies at the Faculty of Management in the first semester of 2019/2020. Tools: To confirm the construct validity and to improve the quality of the measurement model and its application to new dataset, methods that validate the model were applied: Cronbach's alpha, factor analysis, the Heterotrait-Monotrait ratio of correlations and the Fornell-Larcker criterion. To test the hypotheses, the structural equation modelling was used. Findings: The proposed El model achieved statistically significant explanatory power of almost $50 \%$ of the variations in El, due to personal attitude (PA) and perceived behaviour control (PBC). The study adds empirical evidence in the context of Serbian entrepreneurial practice about the role of SN as the antecedent of PA and PBC. Age, a role model and work experience showed statistically significant influence as control variables. Contribution: The study extends the literature by empirically testing Ajzen's theory in the context of an emerging economy and offers an input for practical implementation of findings.
\end{abstract}

Keywords: Entrepreneurship, entrepreneurial intention model, theory of planned behaviour, personal attitude, subjective norm, perceived behaviour control

JEL Classification: L26, M13, M20, O31

\section{Introduction}

The success of entrepreneurial ventures depends on the quality of the entrepreneurial idea and the ability of entrepreneurs to realize it (Vekic, Fajsi \& Borocki, 2019). If we want to enlarge the number of enterprises, a closer explanation of all the phases and predictions of entrepreneurship is necessary. The first step of the entrepreneurship process is the entrepreneurship intention and in order to enlarge this exact phenomenon it is of great importance to look deeply into all the elements which can affect it.

Initial research lists personality attributes as the determinants for entrepreneurial intentions, which are followed by the involvement of individual difference (e.g., achievement motivation) as a significant influencing factor. Nevertheless, potential entrepreneurs are not isolated and autonomous decision makers. They 
are influenced by a large number of micro- and macro-involving factors. According to Neilsen and co-authors, the appropriate leadership style, decentralization, the organic organizational structure and low formalization have a significant positive influence on employees' entrepreneurial intentions (Nielsen, Marinkovic, \& Nikolic, 2019). The creation of preconditions for encouraging corporate entrepreneurship sustains the organisation's long-term competitive position (Nielsen, Babic, Stojanovic-Aleksic, \& Nikolic 2019a). Hockerts' study shows that prior experience predicts social entrepreneurial intentions. The social entrepreneurial self-efficacy both has a strongest impact on intentions and is most responsive to the prior experience (Hockerts, 2017).

Nonetheless, one of the most used theories in entrepreneurial literature is the theory of planned behaviour (TPB), (Schlaegel \& Koenig, 2013) which investigates entrepreneurial behaviour through cognitive and social psychological models.

In addition to social and cultural environment and economic variables, the government and the education system may represent important influencing factors. Government policies and the education system should be oriented in a way that positively influences attitudes or intentions of entrepreneurs and potential entrepreneurs. The involvement of the theory, in this case the intention-based models, can help in creating the suitable education system and policies that support creative thinking, stimulate the entrepreneurship intention and, what is more, the entrepreneurship behaviour (Linan, Rodríguez-Cohard, \& Rueda-Cantuche, 2011). The implementation of long-term strategies of the education system will noticeably increase the entrepreneurial intention (Diez-Echavarria et al., 2019). Literature shows that many studies on various health topics proved that changes in constructing the intention resulted in the change of behaviour. Based on these findings, many successful behaviour changes have been implemented (Fishbein, 2017).

This paper analyses which elements influence the entrepreneurship intention in Serbian entrepreneurial practice and offers input for further practical implementation of findings.

\section{Theory and Hypotheses}

Entrepreneurship is an intentionally planned behaviour resulting from motivation and cognition (Krueger \& Carsrud, 1993, Krueger \& Brazeal, 1994; Krueger, Reilly, \& Carsrud, 2000; Linan, Nabi \& Krueger, 2013; Krueger, 2017). Entrepreneurship can be a career choice, and therefore a conscious and long-planned behaviour. There are also cases where it can present results of a certain coincidental situation. If a surprising and potentially great opportunity appears, an entrepreneur may choose to start his/her mission at the moment. It can be concluded that the exact timing at the beginning of a new venture can be unplanned, nevertheless, the intention of the enterprise creation appears earlier in the entrepreneur's mind. Another possible trigger for the enterprise creation can be a unique event in the life of the entrepreneur, such as being looked down on; nevertheless, in this case, a long-lasting wish and desire to be a business owner preceded this event (Fishbein, 2017; Krueger et al., 2000). The additional attractiveness of entrepreneurship, as a career choice, lies in the possibility to participate in the labour market while retaining personal freedom (Martinez et al., 2007).

The entrepreneurial intention, as a conscious state of mind that precedes action (Shook, Priem, \& McGee, 2003), indicates the effort that a person will make to carry out that entrepreneurial behaviour (Ajzen, 1991). The entrepreneurial intention may be defined as a mental state that represents a strong commitment to take entrepreneurial action in the future; therefore, it is a link between the beliefs of an individual and the corresponding behaviour (Boyd \& Vozikis, 1994). The entrepreneurial intention as a good indicator of a particular action is also considered as a personal orientation that might lead to the venture creation. It can be pointed out that not all entrepreneurial intentions will lead to an action, but it is also true that no action will happen without intention (Krueger et al., 2000).

\subsection{The theory of planned behaviour}

Literature recognizes entrepreneurial intention as a very important concept and in order to study the entrepreneurial intention, numerous different entrepreneurial intention models have been used (Shapero \& Sokol, 1982; Kent, Sexton, \& Vesper, 1982). Among them, the TPB has become the most powerful and prevailing concept in the research on entrepreneurial intention (Fayolle \& Linan, 2014). The central construct in the TPB is the individual's intention to perform a given behaviour (Moriano et al., 2012). The prerequisite for this theory is that the behaviour has to be under volitional control. Since entrepreneurship is con- 
sidered an intentional planned behaviour, it is possible to find the reason why many entrepreneurs, long before recognizing the opportunities for venture creation, have actually already made a decision to start a business (Ajzen, 2002).

The TPB combines two approaches of research into El: the research in the relationships between attitudes and the entrepreneurial intention and the research in the connections between self-efficacy and the entrepreneurial intention (Ajzen, 2001). According to the model, three intentional antecedents predict the intention best: the attitude towards the behaviour or personal attraction (PA), subjective norms (SN) and perceived behavioural control (PBC). PA is a "personal" desirability or a degree to which a person has a positive or negative evaluation or appraisal of the behaviour in question, in this case of being an entrepreneur (Linan \& Chen, 2006). It has been developed on the basis of positive beliefs that are kept together for the benefits of being an entrepreneur such as financial rewards, independence/autonomy, personal rewards and family security, but also a negative impact factor such as a perceived risk (Ozaralli \& Rivenburgh, 2016). SN is a social factor that refers to the perceived social pressure to perform or not to perform the behaviour. In this case, subjective norms refer to the views considered important by individuals who advise the individual to perform or not to perform certain entrepreneurial behaviours. More precisely, it measures whether "reference people" would approve of the decision to become entrepreneurs (Linan and Chen, 2006). Krueger et al. (2000) suggest that those people are parents, significant persons, friends, role models or mentors. PBC or a perceived ability to perform a behaviour refers to the perception of the ease or difficulty of performing the behaviour and is assumed to reflect the past experience as well as the anticipated obstacles (Kolvereid, 1996; Autio, Keeley, Klofsten, Parker, \& Hay 2001; Krueger et al. 2000). It is an individual's belief and confidence in his/her capability of performing the role of an entrepreneur (Ajzen, 2002) and since it is a perception, it can also be called entrepreneurial self-efficacy (Shook \& Bratianu 2010; Moriano et al., 2012). In other words, PBC copes with perceptions, not the actual skills or abilities (Kickul, Gundry, Barbosa, \& Whitcanack, 2009).

The influence of these three motivational antecedents is positive, i.e., the better the attitude, subjective norms and perceived behavioural control, the stronger the intention of an individual to perform the behaviour. (Autio et al., 2001; Krueger et al., 2000).

\subsection{Proposed model of entrepreneurial intention}

The relative contributions of the three motivational factors for the intention explanation differ for each specific behaviour (Autio et al., 2001). Considering the entrepreneurial intention, most of the entrepreneurship literature proves that PBC has the strongest effect (Peterman \& Kennedy, 2003, Ajzen, 1991, Moriano et al., 2012), therefore, it is expected that PBC is more decisive for action (Kolvereid, 1996; Autio et al., 2001; Krueger et al., 2000). There are also studies that do not show any effects of SN on the business entrepreneurial intention (Veciana et al., 2005; Vinogradov et al., 2013; Do Paco et al., 2011; Arrighetti, Caricati, Landini, \& Monacelli, 2016). Guided by those results, some studies simply omitted SN from the initial model (Linan \& Santos, 2007; Linan, 2008) while some, such as Linan with co-authors, found out the role of SN as an antecedent to PA and PBC (Shirokova, Osiyevskyy, \& Bogatyreva, 2016). Taken together, the inconsistencies in defining and modelling $S N$ strongly emphasize the continued need for further research on this antecedent, as well as theoretical elaboration and empirical investigation (Weber, Oser, Achtenhagen, Fretschner, \& Trost, 2014).

By adopting Linan's and Chen's model we conducted the empirical investigation among Serbian management students. We single out age, gender, knowing a role model, having work experience and self-employed experience as exogenous factors that had a positive indirect influence on intention and behaviour through motivational antecedents (Linan \& Chen, 2006; Linan \& Fernandez-Serrano, 2014). Considering that a controversy about the role of $\mathrm{SN}$ in the entrepreneurial intention model exists and that the results of the previous research are different, we hypothesize (Figure 1):

$\mathrm{H1}$ : Personal attitude (PA) positively influences the entrepreneurial intention (EI).

$\mathrm{H} 2$ : Perceived behavioural control (PBC) positively influences the entrepreneurial intention (EI).

H3: Subjective norm (SN) positively influences personal attitude (PA).

$\mathrm{H} 4$ : Subjective norm (SN) positively influences perceived behavioural control (PBC). 


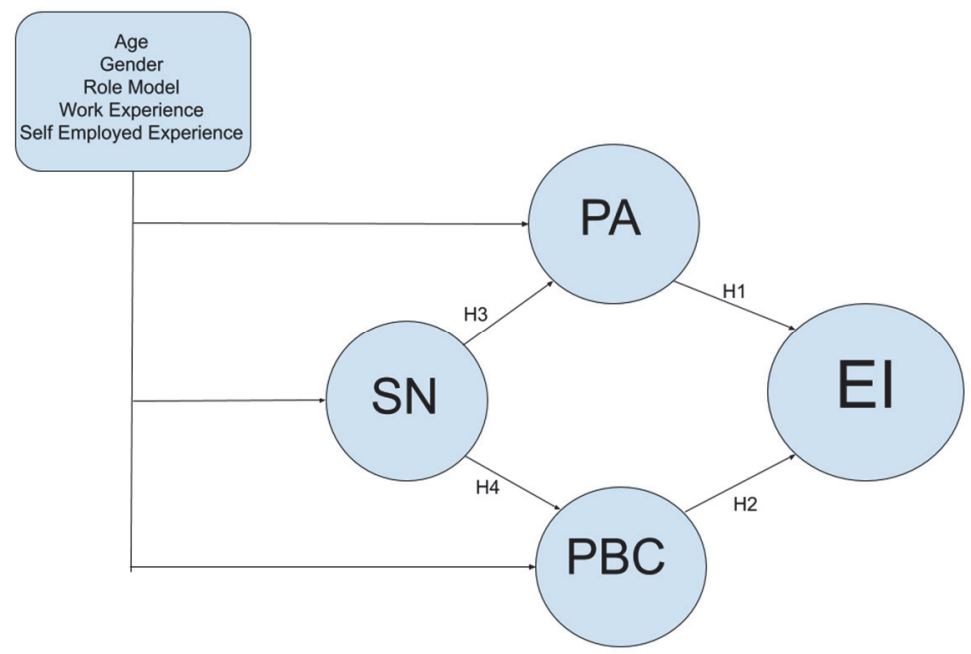

Figure 1: Hypotheses of the entrepreneurial intention model

\section{Methodology}

To test these hypotheses, we used the samples of Master and junior and senior management students from the Faculty of Management in Zaječar (Serbia), Megatrend University, based on convenience and accessibility. Using a student's sample could be considered the most appropriate for this study as the study deals with the entrepreneurial intention of "potential entrepreneurs" (Kickul et al., 2009). We considered particularly management students as the most suitable sample that could develop the intention of starting their own enterprise, due to their formal knowledge. Consequently, the curriculum of the students in our sample includes the courses of entrepreneurship and small business management in their first and second years of university studies. Further, the final year of their studies covers a period of life when career choices can be made and when the time between intention and behaviour is very short and that relation may be more reliable (Conner \& Armitage, 1998). At that period of life, entrepreneurial conscience and the attitude towards entrepreneurship as career have already been formed. Students' involvement in the entrepreneurial activity depends on their career plans and attitude towards self-employment (lakovleva, Kolvereid, \& Stephan 2011). Our initial sample consisted of 196 students. After the exclusion of the questionnaires that had a lot of answers missing, our sample numbered 191.

The data used for the research were primary and they were collected through a questionnaire. At the beginning of the questionnaire, we explained the term entrepreneur, to avoid misunderstanding of this complex term. The e-mail contact was added for possible further dynamic research. Questions about age, gender, knowing an entrepreneur personally (role model), whether they have work experience and self-employment experience (Linan \& Chen, 2009) were included. Questions 6 to 9 correspond to the elements in the entrepreneurial intention model (PA, SN, PBC, EI) and they were all measured by the Likert-type scale (form 1 to 7, the scale is taken from the original Entrepreneurial Intention Questionnaire), since the multi-item scales are more reliable than single ones (Linan \& Chen, 2009). The following table shows the questions that measure the constructs. The questions were previously validated in the study of Linan and Chen (2009) and translated from English with the use of the back-translation strategy.

The questionnaires were handed out in print in classes with the previous explanation of the aim of the questionnaire and the terms used in it, and by doing so we enabled a high percentage of responses.

For data analysis, we used a SmartPLS version 3.2.6. and a SPSS version 23. To test the hypotheses, we used structural equation modelling, tools that are increasingly being used in behavioural science research since it models relationships among multiple independent and dependent variables simultaneously (Linan \& Chen, 2009; Gefen at al., 2000; Esfandiar et al., 2019; lakovleva et al., 2011; Valencia-Arias et al., 2018). 
Table 1: Questions tested

\begin{tabular}{|c|c|}
\hline Construct & Questions \\
\hline \multirow[t]{3}{*}{ SN } & If I decide to set up a firm, my close family will approve of that decision \\
\hline & If I decide to set up a firm, my friends will approve of that decision \\
\hline & If I decide to set up a firm, my colleagues and mates will approve of that decision \\
\hline \multirow[t]{5}{*}{ PA } & Being an entrepreneur implies more advantages than disadvantages to me \\
\hline & A career as an entrepreneur is attractive to me \\
\hline & If I had the opportunity and resources, l'd like to start a firm \\
\hline & Being an entrepreneur would entail great satisfaction for me \\
\hline & Among various options, l'd rather be an entrepreneur \\
\hline \multirow[t]{6}{*}{ PBC } & Starting a firm and keeping it operational would be easy for me \\
\hline & I'm prepared to start a viable firm \\
\hline & I can control the creation process of a new firm \\
\hline & I know the necessary practical details to start a firm \\
\hline & I know how to develop an entrepreneurial project \\
\hline & If I tried to start a firm, I would have a high probability of succeeding \\
\hline \multirow[t]{6}{*}{ El } & I'm ready to do anything to be an entrepreneur \\
\hline & My professional goal is to become an entrepreneur \\
\hline & I will make every effort to start and run my own firm \\
\hline & I'm determined to set up a firm in the future \\
\hline & I have very seriously thought about starting a firm \\
\hline & l've got a strong intention to start a firm some day \\
\hline
\end{tabular}

\section{Results}

The essential psychometrics of the model were tested, and the first part of this section shows the results of reliability and validity tests of the scales, as well as the instrument and the constructs. The second part presents the descriptive statistics, and the last one deals with the results of testing hypotheses.

\subsection{Reliability and validity testing}

For reliability testing, Cronbach's alpha was used as a measure of internal consistency that shows how closely related a set of items are as a group. It is not unusual in social science research situations that the values of 0.7 and higher are considered acceptable (George \& Mallery, 2003). In our case the values ranged from 0.752 to 0.952 and therefore the scales may be considered as reliable.

Table 2: Cronbach's alpha

\begin{tabular}{|l|l|}
\hline Factor & Cronbach's alpha \\
\hline Personal attitudes & 0.898 \\
\hline Social norms & 0.752 \\
\hline Perceived behavioural control & 0.879 \\
\hline Entrepreneurial intention & 0.952 \\
\hline
\end{tabular}

Validity represents the extent to which an instrument is accurate at measuring the construct under study, in this case the dimensions of the entrepreneurial intention (George \& Mallery, 2003). Based on the literature proposition (Linan \& Chen, 2009; George \& Mallery, 2003; Anderson et al.,1988), the substantive validity can be assessed by using the two fundamental aspects of construct validity: convergent validity and discriminant validity.

Convergent validity is usually evaluated with the use of factor analysis, which is a statistical method that "explores the extent to which individual items in a questionnaire can be grouped together according to the correlations between the responses to them", thus reducing the dimensionality of the data (Hutchinson et al., 2006, p. 348). In situations when the factor structure is theory driven, a commonly used method to test the propound factor structure of the questionnaire is confirmatory factor analysis (CFA) (McArdle, 1996). The re- 
sults show that convergent validity can be assured since the factor loadings of the observable variables were higher than 0.5, with the average above 0.7 (Bagozzi \& Yi, 1988).

Table 3: Convergent validity

\begin{tabular}{|c|c|c|c|c|c|}
\hline Construct & $\begin{array}{l}\text { Average Variance } \\
\text { Extracted (AVE) }\end{array}$ & $\begin{array}{l}\text { Composite } \\
\text { reliability }\end{array}$ & Item & $\begin{array}{l}\text { Standardized } \\
\text { factor } \\
\text { loadings }\end{array}$ & $\begin{array}{l}\text { Average } \\
\text { standardized } \\
\text { factor loadings }\end{array}$ \\
\hline \multirow{6}{*}{$\begin{array}{l}\text { Entrepreneurial } \\
\text { intention }\end{array}$} & \multirow{6}{*}{0.808} & \multirow{6}{*}{0.962} & Ela & 0.851 & \multirow{6}{*}{0.898} \\
\hline & & & Elb & 0.888 & \\
\hline & & & Elc & 0.944 & \\
\hline & & & Eld & 0.926 & \\
\hline & & & Ele & 0.884 & \\
\hline & & & Elf & 0.897 & \\
\hline \multirow{5}{*}{$\begin{array}{l}\text { Personal } \\
\text { attitude }\end{array}$} & \multirow{5}{*}{0.716} & \multirow{5}{*}{0.926} & $\mathrm{PAa}$ & 0.761 & \multirow{5}{*}{0.844} \\
\hline & & & PAb & 0.899 & \\
\hline & & & PAC & 0.822 & \\
\hline & & & PAd & 0.902 & \\
\hline & & & $\mathrm{PAe}$ & 0.837 & \\
\hline \multirow{6}{*}{$\begin{array}{l}\text { Perceived } \\
\text { behavioural } \\
\text { control }\end{array}$} & \multirow{6}{*}{0.628} & \multirow{6}{*}{0.910} & $\mathrm{PBCa}$ & 0.677 & \multirow{6}{*}{0.789} \\
\hline & & & $\mathrm{PBCb}$ & 0.857 & \\
\hline & & & PBCc & 0.818 & \\
\hline & & & PBCd & 0.718 & \\
\hline & & & PBCe & 0.809 & \\
\hline & & & PBCf & 0.858 & \\
\hline \multirow{3}{*}{ Subjective norm } & \multirow{3}{*}{0.666} & \multirow{3}{*}{0.857} & $\mathrm{SNa}$ & 0.797 & \multirow{3}{*}{0.816} \\
\hline & & & $\mathrm{SNb}$ & 0.860 & \\
\hline & & & SNc & 0.790 & \\
\hline
\end{tabular}

The Kaiser-Meyer-Olkin Measure of Sampling Adequacy (KMO) and Bartlett's test of sphericity were conducted to test how suited our sample was to the model. The KMO offered statistics that indicated the proportion of variance in the variables that might be caused by underly factors (Child, 1990). Bartlett's test checks if the correlation matrix is an identity matrix that would signify that the variables are unrelated and thus inappropriate for the factor analysis (Levy et al., 2006, Child, 1990).

Table 4: KMO and Bartlett's Test

\begin{tabular}{|cl|}
\hline Kaiser-Meyer-Olkin Measure of Sampling Adequacy. & 0.844 \\
\hline Bartlett's Test of Sphericity Approx. Chi-Square & 3579.351 \\
\hline df & 190 \\
\hline Sig. & 0.000 \\
\hline
\end{tabular}

For our sample, the KMO test showed a high adequacy (0.844) and Bartlett's sphericity test was highly significant $(p<.000)$, thus confirming the possibility to carry out a data reduction technique, and therefore analyse the factors that influence the entrepreneurial intention. The same results showed the coefficients for each of the factors (Table 5).

Table 5: KMO and Bartlett's Test

\begin{tabular}{|l|l|l|}
\hline Factors & Kaiser-Meyer-OIkin value & Bartlett's value \\
\hline Personal attitudes & 0.822 & 0.000 \\
\hline Social norms & 0.592 & 0.000 \\
\hline Perceived behavioural control & 0.864 & 0.000 \\
\hline Entrepreneurial intention & 0.863 & 0.000 \\
\hline
\end{tabular}

Discriminant Validity is the level to which measures of different constructs show correlation with one another (DeVon et al., 2007). The discriminant validity was evaluated by using the heterotrait-monotrait ratio of correlations (HTMT) and the Fornell-Larcker criterion. Fornell-Larcker report supports the discriminant validity of our scales (Table 6) since the comparison of the values in the matrix shows that the square roots of the average variance extracted, i.e., the values in the matrix diagonal, are larger in all cases than the off-diagonal values in their corresponding row and column (Hair, J., Hult, GTM, Ringle C \& Sarstedt, M, 2014). 
Table 6: Fornell-Larcker report

\begin{tabular}{|l|l|l|}
\hline Factors & Kaiser-Meyer-Olkin value & Bartlett's value \\
\hline Personal attitudes & 0.822 & 0.000 \\
\hline Social norms & 0.592 & 0.000 \\
\hline Perceived behavioural control & 0.864 & 0.000 \\
\hline Entrepreneurial intention & 0.863 & 0.000 \\
\hline
\end{tabular}

The HTMT as a new method for assessing discriminant validity outperforms earlier approaches. The confidence interval in the estimate of a correlation between each pair of factors has to be under 0.85 (Voorhees, Brady, Calantone \& Ramirez, 2005) to support discriminant validity. Table 7 proves that this condition is met in our sample and discriminant validity has been established between the reflective constructs.

Table 7: Heterotrait-Monotrait ratio of correlations

\begin{tabular}{|l|l|l|l|l|}
\hline & EI & PA & PBC & SN \\
\hline EI & & & & \\
\hline PA & 0.704 & & & \\
\hline PBC & 0.664 & 0.713 & & \\
\hline SN & 0.279 & 0.440 & 0.533 & \\
\hline
\end{tabular}

\subsection{Descriptive statistics}

The following Tables 2 to 6 present descriptive statistics.

Table 8: Descriptive statistics age

\begin{tabular}{|l|l|l|l|l|l|}
\hline & N & Minimum & Maximum & Mean & $\begin{array}{l}\text { Std. } \\
\text { Deviation }\end{array}$ \\
\hline age & 185 & 21 & 45 & 24.99 & 5.596 \\
\hline
\end{tabular}

\begin{tabular}{|l|r|r|r|r|r|}
\hline Value & $21-25$ & $26-30$ & $31-35$ & $36-40$ & $41-45$ \\
\hline Frequency & $74.6 \%$ & $12.4 \%$ & $3.2 \%$ & $6 \%$ & $3.8 \%$ \\
\hline
\end{tabular}

Table 9: Descriptive statistics

\begin{tabular}{|r|l|l|l|}
\hline & Frequency & Percent & Valid Percent \\
\hline Gender & 185 & 96.9 & 100.0 \\
\hline male & 52 & 27.2 & 28.1 \\
\hline female & 133 & 69.6 & 71.9 \\
\hline missing & 6 & 3.1 & \\
\hline Work experience & 191 & 100.0 & 100.0 \\
\hline yes & 86 & 45.0 & 45.0 \\
\hline no & 105 & 55.0 & 55.0 \\
\hline missing & 0 & 0 & \\
\hline Self-employed experience & 188 & 98.4 & 100.0 \\
\hline yes & 19 & 9.9 & 10.1 \\
\hline no & 169 & 88.5 & 89.9 \\
\hline missing & 3 & 1.6 & \\
\hline Role model & 191 & 100.0 & 100.0 \\
\hline yes & 127 & 66.5 & 66.5 \\
\hline no & 64 & 33.5 & 33.5 \\
\hline missing & 0 & 0 & \\
\hline
\end{tabular}

The average age of students in our sample was 25. A higher percentage of students were female (72\%); the majority did not have any self-employment experience, but even $45 \%$ had some work experience, and almost $67 \%$ had a certain entrepreneur as a role model. 


\subsection{Results of hypotheses testing}

To test the hypotheses, we tried to verify the model explained at the beginning of this paper (Figure 1) with the structural equation modelling. The variables age, gender, presence of a role model, work experience and self-employment experience as control variables were used as items that influenced El only through motivational antecedents (SN, PBC, PA). All the demographic variables are dichotomic, except Age, which is measured in years. The value 1 means male for the "Gender" variable and Yes for other variables (know an entrepreneur personally, have self-employment experience and have work experience). The value 0 means the opposite. Since the posesion of these characteristics may be connected with more favourable perceptions, it is expected that the relationship with all the control variables and intention antecedents is positive.

After running the PLS Algorithm, we obtained the percentage of explained variance by explanatory variables $\left(R^{2}\right)$, factor loadings and standardized regression weights or the effect. The chosen method for the missing value was case wise deletion. We calculated t-statistics to determine with certainty that the regression weights were significant.

Table 10: PLS Algorithm of the model with standardized regression weights, factor loadings and $p$ values

\begin{tabular}{|c|c|c|c|}
\hline & $\begin{array}{l}\text { Standardized } \\
\text { regression weights }\end{array}$ & T Statistics & P Values \\
\hline Age $->$ PA & -0.091 & 1.064 & 0.287 \\
\hline Age -> PBC & 0.044 & 0.478 & 0.633 \\
\hline Age -> SN & -0.263 & 2.749 & 0.006 \\
\hline Gender -> PA & 0.105 & 1.417 & 0.157 \\
\hline Gender -> PBC & 0.086 & 1.202 & 0.230 \\
\hline Gender -> SN & -0.140 & 1.920 & 0.055 \\
\hline $\mathrm{PA}->\mathrm{El}$ & 0.416 & 5.669 & 0.000 \\
\hline PBC -> El & 0.354 & 4.927 & 0.000 \\
\hline Role.model -> PA & 0.106 & 1.504 & 0.133 \\
\hline Role.model -> PBC & 0.176 & 2.840 & 0.005 \\
\hline Role.model -> SN & 0.096 & 1.242 & 0.214 \\
\hline SN $->$ PA & 0.356 & 4.701 & 0.000 \\
\hline SN -> PBC & 0.488 & 7.961 & 0.000 \\
\hline Self.empl. -> PA & -0.008 & 0.094 & 0.925 \\
\hline Self.empl. -> PBC & 0.095 & 1.241 & 0.215 \\
\hline Self.empl. -> SN & 0.028 & 0.332 & 0.740 \\
\hline Work.exp. -> PA & 0.198 & 2.246 & 0.025 \\
\hline Work.exp. -> PBC & 0.082 & 1.151 & 0.250 \\
\hline Work.exp. -> SN & 0.243 & 2.998 & 0.003 \\
\hline
\end{tabular}

Then, with the recursive method applied, we eliminated the path with the lowest t-statistic and repeated with each iteration until all coefficients were significant at the $95 \%$ level of confidence and higher. For the purposes of clarity, the entrepreneurial intention model with only significant paths included is given in Figure 2 . The model shows the negative influence of Age on SN, the positive influence of Role model on PBC and the positive influence of Work experience on SN and PA. SN has influence on El, but the indirect one, only through PA and PBC. PA and PBC have a statistically significant direct influence on El, the stronger one being the influence of PA. Our model explained almost $50 \%$ of variance of El $(49.8 \%)$. Therefore, it can be argued that all four hypotheses are proven. 


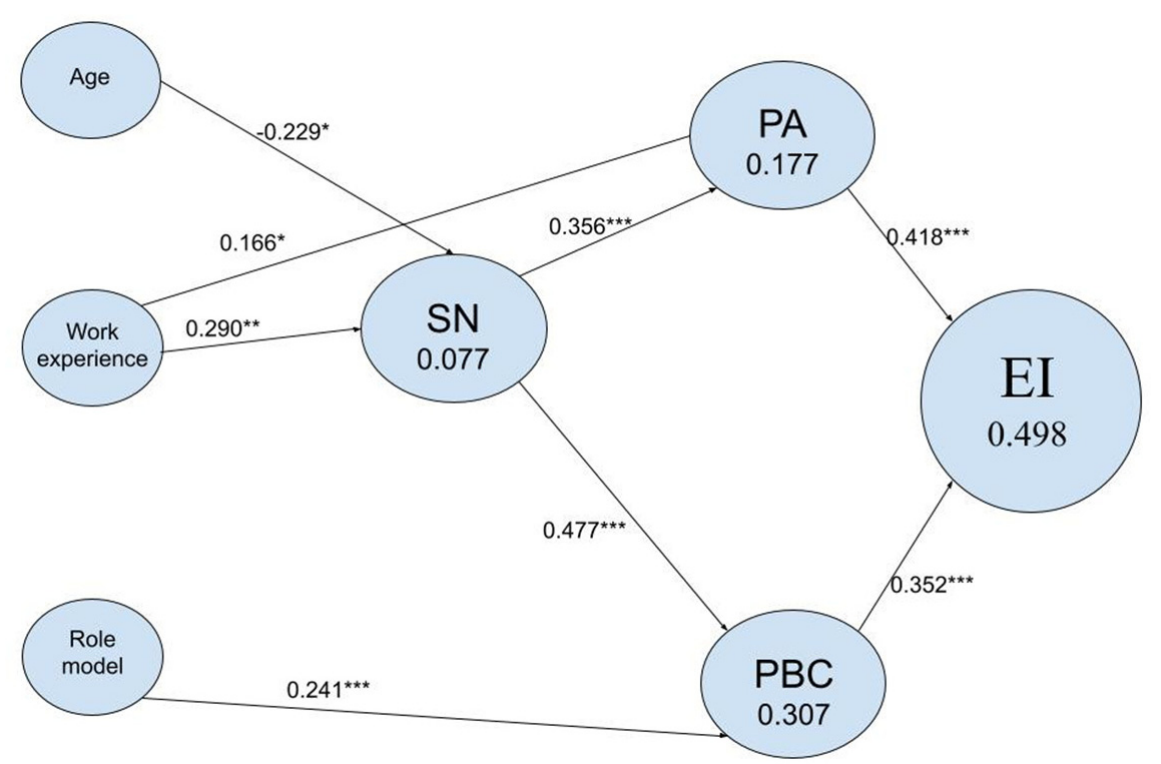

Figure 2: Entrepreneurial intention model based on results with standardized regression weights, factor loadings and $\mathrm{R} 2$

${ }^{*} \mathrm{p}<0.05 ;{ }^{* *} \mathrm{p}<0.01 ;{ }^{* * *} \mathrm{p}<0.000$

\section{Discussion}

As seen in the previous section, all hypothesized relations are completely accepted: PA and PBC have a statistically significant direct positive influence on $\mathrm{El}$, while SN has a positive influence on PA and PBC. These findings are in accordance with some previous findings in the literature in which subjective norms show a low or insignificant influence on entrepreneurial intentions (e.g., Krueger et al., 2000; Linan \& Chen, 2006; Do Paco et al., 2011, Linan \& Chen, 2009, Linan et al., 2011, Arrighetti et al., 2016, Vinogradov et al., 2013,). Out of all of the relationships in the entrepreneurial intention model in TPB, subjective norms to intentions received the lowest support in literature (Lortie \& Gastogiovanni's, 2015). Certain entrepreneurship scholars theorized that SN might act as an antecedent to PA or PBC (Boyd \& Vozikis 1994). Linan and Chen empirically proved that SN would be „the first step in the mental process, acting as a first filter to external stimuli and thus influencing perceptions of PA and PBC" (Linan \& Chen, 2009, p.612) and called for a contribution to the study in different countries. Hence, this research gives empirical evidence that the relationships of $S N$ and $\mathrm{El}$ are being mediated by PA and PBC with regard to senior management students in Serbia.

This can be understood as a fact that if social pressure to become an entrepreneur exists, it does not influence the entrepreneurial intention of the individual directly. This indicates that the choice of entrepreneurship as a career is based on one's own introspection and it may be interpreted as the fact that most of the students from the sample are in control of their lives. Nevertheless, the effects of SN should not still be refused totally. Moving further from the direct influence, consideration of the indirect effect that SN has via PA and PBC on El shows better results. Therefore, rather than directly changing a person's intentions to become an entrepreneur, the approval of family, friends and colleagues of such a career choice persuades individuals to recognise it even as more favourable and gives them higher self-confidence that they can prove themselves. Hence, as stated previously, such positive perceptions result in higher entrepreneurial intentions.

Our model explains a very high percentage of variance of El.

While in most studies PBC has the strongest influence on $\mathrm{El}$, in this study the most powerful one is the influence of PA. The explanation may be found in some cultural or social factors or it may be in the differences between the education programmes. The PBC component represents students' own perception of their appraisal of knowledge and skills in a new venture creation. Thus, students indicated that during studies they acquired a wider range of entrepreneurial skills and knowledge that can be applied after graduation. However, in our sample, the explanatory power of PBC in predicting El is lower than the power of PA. It can be interpreted that, although students have certainly learned something at university, these newly acquired skills and knowledge are not so relevant to their decision to become entrepreneurs (Weber et al., 2014) as personal desirability of being an entrepreneur. 
As far as age is concerned, even though the average age of the students in our sample is 25 , it should be mentioned that we had a group of respondents that dramatically differed in age (from 21 to 45), therefore it was possible to explain how age affected the entrepreneurial intention. Surprisingly, the influence is negative, showing that younger people have higher intentions to pursue an entrepreneurial career. The explanation can be found in suggestions that the young people, regardless of the risk levels, show greater intentions to venture creation when they identify a good idea (Diez-Echavarria et al., 2019). Additionally, in emerging economies (such as our case) the possibilities of having steady jobs for younger people are also weaker, which suggests that being an entrepreneur presupposes not so high economic and social risks as in developed countries (Diez-Echavarria et al., 2019). Empirical results from the survey conducted by CEVES in Serbia reveal that $65 \%$ of the citizens answered that they would like to work for the salary in the public sector and just 30\% would like to start their own business; in the same survey the youngest (aged 18 to 29) had the highest percentage of desire to be self-employed (36\%) (CEVES, 2014).

It is more than evident that in the last three decades, female entrepreneurship has made a significant progress (Kickul et al., 2008). Nowadays there are more women who are self-confident and ready to take a risk. Consequently, women as entrepreneurs are of ever increasing economic and social importance. Our study only confirmed that the gender did not have a statistically significant influence on entrepreneurial intention.

The role model confirmed a statistically significant positive influence on El. This influence is also indirect, through motivational antecedents, actually through PBC. The influence can be explained by the logic that if an entrepreneur and his/her business are in a position to observe closer possible advantages and obstacles of the business, then it helps individuals to get their own impression of how easy or difficult it is to be an entrepreneur and to enlarge their personal desirability for entrepreneurship. The study of Nowinski and Haddoud confirms this and suggests that the key to promoting El lies in the interplay of role models, attitudes towards entrepreneurship and entrepreneurial self-efficacy (Nowinski \& Haddoud, 2019). Whether role model activities are related to storytelling, especially successful role model and idol stories, (Liu et al., 2019), or involving the respondent in professional activities, or employment (Auken et al., 2006), they are more inclined to arouse the individuals' El by forming particular guidance and support, or by creating the environment that prompts entrepreneurial behaviour (Barnir et al., ).

According to the results of this study, work experience has a statistically positive significant influence. The literature on the empirical results of other countries confirms our findings (Masoomi et al., 2016; Soria-Baretto et al., 2017; Yuan et al., 2019). The entrepreneurial intention and behaviour are often considered a result of previous work experience. Moreover, because of the lack of previous work experience, even if a student has a firm entrepreneurial intention, he/she might not act upon it until he/she accumulates enough experience to gain confidence to create the venture (Carsrud \& Brannback, 2011).

Previous entrepreneurial experience of an entrepreneur can be considered as one of the main factors linked to the new venture creation (Lee \&Tsang, 2001). However, our results show insufficient statistical evidence that lead to the fact that students with prior self-employment experience show a higher level of entrepreneurial intention. The explanation for this can be found in the specific overall economic situation in Serbia. Students generally have little self-employment experience and the attitude toward entrepreneurship is mostly negative in Serbia (CEVES, 2014). In our sample, even $10 \%$ of the respondents confirmed that they were previously self-employed, with approximately 5.7 years of this experience (the answers of the length of self-employment were 1 to 12 years). Nevertheless, at the moment of survey all of them declared that they were not self-employed anymore. These findings call for further research. Further studies should apply additional qualitative methodology in order to gain more thorough findings.

Concluding Remarks and Implications

Our study enlarges the current body of literature with additional empirical evidence of the implication of TPB on entrepreneurial intention. The TPB has shown to be applicable to entrepreneurship, and this time the model has been proven via the sample of management students from an emerging economy. Another contribution of the paper is in delivering empirical proofs to the ongoing debate of the influence of subjective norms. Since some previous studies have not confirmed a significant direct relationship between subjective norms and the entrepreneurial intention, social capital literature indicates that these norms favourably affect PA and PBC (Linan et al., 2011a). The results of this paper support doubt in the direct relationship and suggest that the role of subjective norms should just be antecedent to PA and PBC. 
The model explains a very high percentage of variance of El via PA and PBC, and while both influences are positive, the one of PA is stronger. Therefore, in order to enlarge the entrepreneurial intention, the most important issue in Serbia, means to have positive personal attitudes towards being an entrepreneur. By continuously fostering the entrepreneurial atmosphere and culture, we believe that the population could identify the benefits and positive elements of starting a business in the long run. Secondly, entrepreneurial self-efficacy or the individual's belief and confidence in his/her capability of acting as an entrepreneur can be enlarged by getting to know more closely what it means to be an entrepreneur, what the real obstacles from concrete examples are and how they have been overcome. Entrepreneurial education should be designed in the way that students can identify themselves as entrepreneurs and realise the feasibility of achieving an entrepreneurial venture and the benefits of entrepreneurial activities. The educational system should be connected with economy, through mutual projects, for instance bringing successful entrepreneurs as external lecturers, organizing competitions for the most creative ideas and business models, connecting students and professors from different areas in order to create start-ups and spinoffs, introducing dual education by sending most promising students to certain enterprises, etc.

This study was conducted in the context of Serbia and the basic limiting factor is a small sample. Since the use of quantitative methodology has created a significant limitation in the future studies, we suggest the application of mixed method in order to provide a holistic research methodology. It is especially important to apply the qualitative method to assess more in-depth influences of prior self-employment experience. The application of qualitative interviewing, as a very valuable method of investigating practical fields in human sciences, would enable a better explanation of meaning and a better interpretation of the observed phenomena and elements. In future research, it would be interesting to expand the research to students from different fields of study, as well as to students from other countries, which would give us a broader insight into the research question, and an opportunity to compare results by countries.

\section{REFERENCES}

[1] Ajzen, I. (1991). The theory of planned behaviour. Organizational behaviour and human decision processes, 50 (2), 179-211. DOI: 10.1016/0749-5978(91)90020-T

[2] Ajzen, I. (2001). Nature and operation of attitudes. Annual review of psychology, 52 (1), 27-58. DOI: 10.1146/annurev.psych.52.1.27

[3] Ajzen, I. (2002). Perceived behavioural control, self-efficacy, locus of control, and the theory of planned behaviour. Journal of Applied Social Psychology, 32, 1-20. DOI: 10.1111/j.1559-1816.2002.tb00236.x

[4] Anderson, J.C.; Gerbing, D.W. (1988). Structural equation modelling in practice: A review and recommended two-step approach. Psychological Bulletin, 103 (3), 411-423. DOI: 10.1037/00332909.103.3.411

[5] Arrighetti, A., Caricati, L., Landini, F. and Monacelli, N. (2016). Entrepreneurial intentions in the time of crisis: a field study. International Journal of Entrepreneurial Behaviour and Research, 22 (6), 835-859. DOI: $10.1108 / I J E B R-12-2015-0326$

[6] Auken, H.V., Fry, F. \& Stephens, P. (2006). The influence of role model on entrepreneurial intentions. Journal of Developmental entrepreneurship, 11 (2), 157-167, DOI:10.1142/S1084946706000349

[7] Autio, E.H., Keeley, R., Klofsten, M.G.C., Parker, G., \& Hay, M. (2001). Entrepreneurial intent among students in Scandinavia and in the USA. Enterprise and Innovation Management Studies, 2 (2), 145160. DOI: $10.1080 / 14632440110094632$

[8] Bagozzi, R.P., \& Yi, Y. (1988). On the evaluation of structural equation models. Journal of the Academy of Marketing Science, 16 (1), 74-94. DOI:10.1007/BF02723327

[9] Barnir, A., Watson, W. \& Hutchins, H. (2011). Mediation and moderated mediation in the relationship among role models, self-efficacy, entrepreneurial career intention and gender. Journal of applied social psychology 41 (2), 270-297. DOI: 10.1111/j.1559-1816.2010.00713.x

[10] Boyd, N. G., \& Vozikis, G. S. (1994). The influence of self-efficacy on the development of entrepreneurial intentions and actions. Entrepreneurship Theory and Practice,18 (4), 63-77. DOI: $10.1177 / 104225879401800404$

[11] Carsrud, A., \& Brannback, M. (2011). Entrepreneurial motivations: what do we still need to know?. Journal of Small Business Management, 49 (1), 9-26. DOI: 10.1111/j.1540-627X.2010.00312.x

[12] CEVES (2014), "Preduzetništvo u Srbiji, nužda ili prilika?". Retrieved from http://ceves.org.rs/wpcontent/uploads/2014/02/Preduzetnistvo-u-Srbiji.pdf-

[13] Child, D. (1990). The essentials of factor analysis. (2nd ed) Cassell Educational. New York, US.

[14] Conner, M., \& Armitage, C. J. (1998). Extending the theory of planned behaviour: A review and avenues for further research. Journal of Applied Social Psychology, 28 (15), 1429-1464. DOI:10.1111/j.15591816.1998.tb01685.x

[15] DeVon, H.A., Block, M.E., Moyle-Wright, P., Ernst, D.M., Hayden, S.J., Lazzara, D.J., Savoy, S.M., \& Poisten, K. (2007). A psychometric toolbox for testing validity and reliability. Journal of nursing scholarship, 39 (2), 155-164. DOI: 10.1111/j.1547-5069.2007.00161.x 
[16] Diez-Echavarriaa, L., Ariasa, A.V., Bermudez- Hernandeza, J., Perezb, F.O.M., Marinc, M.L.U. \& Velasquezc, J.A.T. (2019). Extension of the systematic entrepreneurship intention model in university students. Serbian Journal of Management 14 (2), 277 - 297. DOI:10.5937/sjm14-17336

[17] Do Paco, A. M. F., Ferreira, J. M., Raposo, M., Rodrigues, R. G., \& Dinis, A. (2011). Behaviours and entrepreneurial intention: Empirical findings about secondary students. Journal of International Entrepreneurship, 9 (1), 20-38. DOI: 10.1007/s10843-010-0071-9

[18] Esfandiar, K., Sharifi-Tehrani, M., Pratt, S., Altinay, L. (2019). Understanding entrepreneurial intentions: A developed integrated structural model approach. Journal of Business Research, 94, 172-182. DOI:10.1016/j.jbusres.2017.10.045

[19] Fayolle, A., \& Linan, F. (2014). The future of research on entrepreneurial intentions. Journal of Business Research, 67 (5), 663-666. DOI: 10.1016/j.jbusres.2013.11.024

[20] Fishbein, D. H. (2017). Biological perspectives in criminology. Criminology 28 (1), 3-48, DOI: 10.1111/j.1745-9125.1990.tb01317.x

[21] Gefen, D., Straub, D.W., \& Boudreau, M.C. (2000). Structural equation modelling and regression: Guidelines for research practice. Communications of the Association for Information Society, 4 (7), 177. DOI:10.17705/1CAIS.00407

[22] George, D., \& Mallery, P. (2003). SPSS for Windows step by step: A simple guide and reference. 11.0 update (4th ed.). Boston: Allyn \& Bacon.

[23] Hair, J., Hult, GTM, Ringle, C. \& Sarstedt, M. (2014) A Primer on Partial Least Squares Structural Equation Modeling (PLS-SEM). Los Angeles: SAGE Publications, Incorporated

[24] Hockerts, K. (2017). Determinants of social entrepreneurial intentions. Entrepreneurship Theory and Practice, 41 (1), 105-130, DOI: 10.1111/etap.12171

[25] Hutchinson, A., Cooper, K., Dean, J., Mclntosh, A., Patterson, M., Stride, C., Laurence, B.E., \& Smith, C.M. (2006). Use of a safety climate questionnaire in UK health care: factor structure, reliability and usability. Quality and Safety in Health Care, 15 (5), 347-353. DOI:10.1136/qshc.2005.016584

[26] lakovleva, T., Kolvereid, L., \& Stephan, U. (2011). Entrepreneurial intentions in developing and developed countries. Education + Training, 53 (5), 353-370. DOI 10.1108/00400911111147686

[27] Kent, C., Sexton, D. L., \& Vesper, K. (1982). Encyclopaedia of entrepreneurship. Englewood Cliffs, NJ : Prentice-Hall.

[28] Kickul J., Wilson F., Marlino D., \& Barbosa S.D. (2008). Are misalignments of perceptions and selfefficacy causing gender gaps in entrepreneurial intention among our nation's teens? Journal of Small Business Entrepreneurship. Dev., 5 (2), 321-335. DOI 10.1108/14626000810871709

[29] Kickul, J., Gundry, L. K., Barbosa, S. D., \& Whitcanack, L. (2009). Intuition versus analysis? Testing differential models of cognitive style on entrepreneurial self-efficacy and the new venture creation process. Entrepreneurship Theory and Practice, 33 (2), 439-453.

[30] Kolvereid, L. (1996). Prediction of employment status choice intentions. Entrepreneurship Theory and practice, 21 (1), pp. 47-58. DOI:10.1177/104225879602100104

[31] Krueger Jr, N. F., Reilly, M. D., \& Carsrud, A. L. (2000). Competing models of entrepreneurial intentions. Journal of business venturing, 15 (5-6), 411-432.

[32] Krueger, Jr, N. F., \& Brazeal, D. V. (1994). Entrepreneurial potential and potential entrepreneurs. Entrepreneurship theory and practice, 18 (3), 91-104.

[33] Krueger, N. F. (2017). Entrepreneurial intentions are dead: Long live entrepreneurial intentions. In M. Brannback \& A. Carsrud, Revisiting the Entrepreneurial Mind (pp. 13-34). Springer, Cham.

[34] Krueger, N. F., \& Carsrud, A. L. (1993). Entrepreneurial intentions: applying the theory of planned behaviour. Entrepreneurship \& Regional Development, 5 (4), 315-330. DOI:10.1080/08985629300000020

[35] Lee, DY, \& Tsang, EW. (2001). The effects of entrepreneurial personality, background and network activities on venture growth. Journal of Management Studies, 38 (4), 583-602.

[36] Levy, K. N., Clarkin, J. F., Yeomans, F. E., Scott, L. N., Wasserman, R. H., \& Kernberg, O. F. (2006). The mechanisms of change in the treatment of transference focused psychotherapy. Journal of Clinical Psychology, 62, 481-501. DOI: 10.1002/jclp.20239

[37] Linan, F. (2008). Skill and value perceptions: how do they affect entrepreneurial intentions? International Entrepreneurship and Management Journal, 4 (3), 257-272. DOI 10.1007/s11365-008-0093-0

[38] Linan, F., \& Chen, Y. W. (2006). Testing the entrepreneurial intention model on a two-country sample. (Working Papers 0607), Departament Empresa, Universitat Autonoma de Barcelona.

[39] Linan, F., \& Chen, Y.W. (2009). Development and Cross-Cultural application of a specific instrument to measure entrepreneurial intentions. Entrepreneurship theory and practice, 33 (3), 593617.DOI:10.1111/j.1540-6520.2009.00318.x

[40] Linan, F., \& Fernandez-Serrano, J. (2014). National culture, entrepreneurship and economic development: different patterns across the European Union. Small Business Economics, 42 (4), 685-701. DOI: $10.1007 / \mathrm{s} 11187-013-9520-\mathrm{x}$ 
[41] Linan, F., \& Santos, F. J. (2007). Does social capital affect entrepreneurial intentions? International Advances in Economic Research, 13 (4), 443-453. DOI: 10.1007/s11294-007-9109-8

[42] Linan, F., Nabi, G., \& Krueger, N. (2013). British and Spanish entrepreneurial intentions: A comparative study. Revista de economía Mundial, 33, 73-103.

[43] Linan, F., Rodríguez-Cohard, J. C., \& Rueda-Cantuche, J. M. (2011). Factors affecting entrepreneurial intention levels: a role for education. International entrepreneurship and management Journal, 7 (2), 195-218. DOI:10.1007/s11365-010-0154-z

[44] Linan, F., Urbano, D. \& Guerrero, M. (2011a). Regional variations in entrepreneurial cognitions: start-up intentions of university students in Spain. Entrepreneurship \& Regional Development, 23 (3-4): 187-215. DOI: $10.1080 / 08985620903233929$

[45] Liu, F., Ma, J., \& Li, R. (2019). Which role model is more effective in entrepreneurship education? An investigation of storytelling on individual's entrepreneurial intention. Frontiers in psychology.10 (837). DOI: $10.3389 /$ fpsyg.2019.00837

[46] Lortie, J. \& Castogiovanii, G. (2015). The Theory of Planned Behavior in Entrepreneurship Research: What We Know and Future Directions. International Entrepreneurship and Management Journal, 11 (4), 935-937. 10.1007/s11365-015-0358-3

[47] Martinez, D., MORA, J. G., \& Vila, L. E. (2007). Entrepreneurs, the Self-employed and Employees amongst young European higher education Graduates. European Journal of Education, 42 (1), 99-117. DOI:10.1111/j.1465-3435.2007.00285.x

[48] Masoomi, I.E., Zamani, N., Bazrafkan, K., \& Akbari, M. (2016). An investigation of the factors influencing entrepreneurial intention of senior agricultural students at Shiraz University. 6 (4), 431-437. DOI: 10.22004/ag.econ.262609

[49] McArdle, J. J. (1996). Current Directions in Structural Factor Analysis. Current Directions in Psychological Science, 5 (1), 11-18. DOI: 10.1111/1467-8721.ep10772681

[50] Moriano, J. A., Gorgievski, M., Laguna, M., Stephan, U., \& Zarafshani, K. (2012). A cross-cultural approach to understanding entrepreneurial intention. Journal of career development, 39 (2), 162-185. DOI:10.1177/0894845310384481

[51] Nielsen, J. E., Babic, V., Stojanovic-Aleksic, V., \& Nikolić, J. (2019). Driving forces of employees' entrepreneurial intentions - leadership style and organizational structure. Management: Journal of Sustainable Business \& Management Solutions in Emerging Economies, 24 (3): 59-69. DOI: 10.7595/management.fon.2019.0020

[52] Nielsen, J.E., Marinkovic, V., \& Nikolic, J. (2019) a. A strategic approach to organizational entrepreneurship: employees' awareness of entrepreneurial strategy. Economic Annals, 64 (222): 117 146, DOI:10.2298/EKA1922117E

[53] Nowinski, W., \& Haddoud, M. (2019). The role of inspiring role models in enhancing entrepreneurial intention. Journal of Business Research, 96: 183-193, DOI: 10.1016/j.jbusres.2018.11.005

[54] Ozaralli N. \& Nancy K. Rivenburgh. (2016). Entrepreneurial intention: antecedents to entrepreneurial behaviour in the U.S.A. and Turkey, Journal of Global Entrepreneurship Research, 6 (3) DOI:10.1186/s40497-016-0047

[55] Peterman, N. E., \& Kennedy, J. (2003). Enterprise education: Influencing students' perceptions of entrepreneurship. Entrepreneurship theory and practice, 28 (2), 129-144. DOI:10.1046/j.15406520.2003.00035.x

[56] Schlaegel, C., \& Koenig, M. (2014). Determinants of Entrepreneurial Intent: A Meta-Analytic Test and Integration of Competing Models. Entrepreneurship. Theory and Practice, 38 (2), 291332. DOI:10.1111/etap.12087

[57] Shapero, A. \& Sokol, L. (1982). Social dimensions of entrepreneurship. In Kent, C.A., Sexton, D.L. \& Vesper, K.H. (Eds.): Encyclopaedia of entrepreneurship. Prentice Hall, Englewood Cliffs (pp.72-90).

[58] Shirokova, G., Osiyevskyy, O., \& Bogatyreva, K. (2016). Exploring the intention-behaviour link in student entrepreneurship: Moderating effects of individual and environmental characteristics. European Management Journal, 34 (4), 386-399. DOI:10.1016/j.emj.2015.12.007

[59] Shook, C. L., Priem, R. L., \& McGee, J. E. (2003). Venture creation and the enterprising individual: A review and synthesis. Journal of management, 29 (3), 379-399. DOI:10.1016/S0149-2063(03)00016-3

[60] Shook, C.L. \& Bratianu, C. (2010). Entrepreneurial Intent in a Transitional Economy: An Application of the Theory of Planned Behavior to Romanian Students. International Entrepreneurship Management Journal, 6, 231-347. DOI: 10.1007/s11365-008-0091-2

[61] Soria-Barreto,K., Honores-Marin, G., Gutiérrez-Zepeda, H., \& Gutiérrez-Rodríguez, J. (2017). Prior exposure and educational environment towards entrepreneurial intention. Journal of technology management and innovation 12 (2), 45-58. DOI:10.4067/S0718-27242017000200006

[62] Valencia-Ariasa, A., Montoyab, I., Montoya A. (2018). Constructs and relationships in the study of entrepreneurial intentions in university students. International journal of environmental \& science education, 13 (1), 31-52. 
[63] Veciana, J. M., Aponte, M., \& Urbano, D. (2005). University students' attitudes towards entrepreneurship: A two countries comparison. The International Entrepreneurship and Management Journal, 1 (2), 165182, DOI: $10.1007 / \mathrm{s} 11365-005-1127-5$

[64] Vekic, A., Fajsi, A., \& Borocki, J., (2019). Development of entrepreneurial ecosystem through university's new companies. Management: Journal of Sustainable Business and Management Solutions in Emerging Economies, 24 (3), 33-47. DOI: 10.7595/management.fon.2019.0012

[65] Vinogradov, E., Kolvereid, L. \& Timoshenko, K. (2013). Predicting entrepreneurial intentions when satisfactory employment opportunities are scarce. Education + Training, 55 (7), 719-737., DOI:10.1108/ET-06-2012-0067

[66] Voorhees, C.M., Brady, M.K., Calantone, R., \& Ramirez, E., (2015). Discriminant validity testing in marketing: an analysis, causes for concern, and proposed remedies. Journal of the Academy of Marketing Science 44 (1), 119-134, DOI: 10.1007/s11747-015-0455-4

[67] Weber, S., Oser, F., Achtenhagen, F., Fretschner, M. \& Trost, S. (2014). Becoming an entrepreneur. Sense publishers, Roterdam

[68] Yuan, L.W., Qalati, S.A., Iqbai, S., Hussain, R.Y., \& Ali, S. (2019). Impact of prior work experience on entrepreneurial intention and theory of planned behaviour in the context of Pakistan. Journal of Entrepreneurship and Organization Management, 8 (2), 1-9. DOI: 10.4172/2169-026X.1000268

Received: 2020-06-08

Revisions requested: 2020-09-12

Revised: 2020-10-08 (1 revision)

Accepted: 2020-11-02

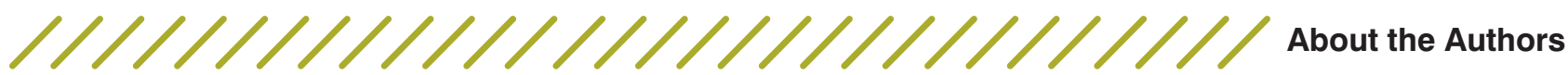

\section{Marija Nikolić Tošović \\ LUM Jean Monnet University, Faculty of Economics, Italy mmarija.nnikolic@gmail.com}

Marija Nikolić Tošović received her PhD at the LUM Jean Monnet University, Faculty of Economics in Casamassima, Bari, Italy. She was a visiting researcher at the ICRE8 research centre in Athens. Her current research interests include entrepreneurship, social entrepreneurship, international entrepreneurship, comparative research, organizational behaviour, cross culture management, and sustainable development.

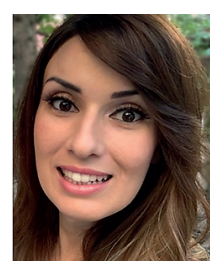

Violeta Jovanović Megatrend University, Faculty of Management Zaječar, Serbia violeta.jovanovic@fmz.edu.rs

Violeta Jovanović, PhD, is active in the fields of sustainable development, research and development management, organization and business management. She did her bachelor's and master's degrees in Bor, at the Technical Faculty. Her doctoral thesis titled "Organizational learning as an influencing factor of sustainable management companies" was defended in 2016 at the Faculty of Management Zajecar. She is a reviewer and a member of the Association of Economists and Managers of the Balkans.

She has published several books and peer-reviewed papers. Her papers are cited in scientific literature. The largest number of papers deals with sustainable development, organizational learning and social responsibility. Since 2017 she has been an assistant professor at the Megatrend University, Faculty of Management Zaječar.

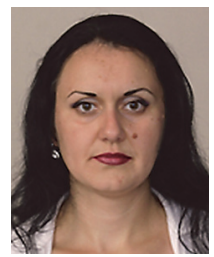

